\title{
1
}

\section{Financial Landscapes Reconstructed}

\author{
F.J.A. Bouman and Otto Hospes
}

We chose the landscape metaphor designedly for this collection of readings on financial intermediation. With it we hope to stimulate reflection on all the critical dimensions of financial and quasi-financial services in the processes of development. The metaphor is not only used to indicate the physical features of the financial landscape such as the offices of banks, cooperatives, credit unions, traders, pawnbrokers, self-help groups, NGOs, and whatever other financial or quasi-financial institutions there may be. With the metaphor we wish to emphasize regional diversity and historical change in financial eco-systems. At the same time it stimulates us to explore what relations, norms, actions and processes influence, directly or indirectly, the transactions of savers, borrowers and lenders.

\section{Landscapes}

The landscape metaphor leads us to expect variety: lowlands and mountain ranges, broad rivers and little streams, fertile regions, deserts and muddy swamps, urging us to adopt a view on a totality, and to ground the institutions and social processes we study in space and time (Benda-Beckmann 1992). The metaphor points at the planned or spontaneous growth of financial intermediaries and relations as well as their predictable, unforeseen or even unnoticed decline - explaining the ever changing composition of financial eco-systems that do not evolve in one particular direction.

Furthermore, landscapes remind us of the physical infrastructure of a region, with different ways to travel from farm fields to market places, from houses to offices, from village markets to wholesale markets, and of poor roads connecting distant villages with capital cities. This leads one to explore the other interesting avenue of financial landscapes: the connections and disconnections between different kinds of savers, borrowers and lenders. The metaphor directs the attention to "networks" of moneylending traders, money guards, banks and savings clubs, but also to deliberate non-use of financial services and short-circuits between financial intermediaries. For instance, inflation causes people to find refuge in "inflation hedges" in the form of golden necklaces and cattle, while political maneuvers might keep savings clubs and money guards from entrusting even a single penny to a bank. Finally, we should not ignore indirect links, as when agricultural traders partly on-lend their bank loans to farmer-borrowers; or when market women who borrow from a wholesaler, deposit money at a local bank and participate in a savings and credit association, thus connecting different financial flows and intermediaries.

Besides leading us to expect diversity and change in financial eco-systems, the metaphor also brings us to systematically explore their backgrounds, that is, why, how and on what scale changes of landscape take place. The metaphor refers to the complex dynamics of changing ecological conditions and human intervention, that include soil conditions, natural vegetation and crops, but also fertilization, salinization, and deforestation as well as natural phenomena like hurricanes, drought and floods. Diversity of landscapes is a result of different and frequently contradictory efforts at planning by individual and institutional actors who face and adapt themselves to specific ecological conditions and changes.

The metaphor of financial landscapes cautions us right from the start against too easy assumptions about the dynamics of financial intermediaries and relations between borrowers, lenders and savers. The quality and effectiveness of the maps of financial landscapes are very much dependent on the uses one needs them for. We want to distinguish two types of orientation: one that is leading us to a better knowledge and theoretical understanding of what we think the real financial landscapes to be; another that enables the promotion of policies and projects directed at change of financial landscapes or the "cultivation" of financial landscapes (BendaBeckmann 1992).

\section{Looking at Financial Landscapes}

"The landscape metaphor allows us to develop different contextual approaches for the analysis and evaluation of financial services in interlinked processes related to the development of state administrations, markets and communities (Eldijk 1992)." One approach might be to look at evolving social-economic relations between mutually dependent traders and farmer-borrowers (Hendriks, chapter 13), or at moral standards governing lending behavior of village shopkeepers in crisis situations (Southwold-Llewellyn, chapter 15). Another is to evaluate the impact of financial-political maneuvers, such as a change of the central bank's rate of discount and 
the passing of Moneylenders or Pawnbrokers Acts (Skully, chapter 21) that aim to regulate their number and conduct. But also a sudden increase in money circulation related to changes of consumption standards and increasing transport facilities is relevant because it can bring a financial landscape to erupt (Hospes, chapter 14). Soaring inflation and monetary instability can cause disintegration of the landscape, frustrating the accumulation of domestic funds in banks or self-help groups. Policies that promote the pouring of easy money into thirsty economies are yet another example: they can easily result in the destruction of financial intermediation structures (Seibel, chapter 2) - only increasing the number of graveyards in financial landscapes. Equally significant are measures that inadvertently influence the emergence and retreat of certain intermediaries, such as land reforms causing landlords to withdraw from the sphere of agricultural credit and traders and input suppliers to step in and fill the void (Crow, chapter 16; Hendriks, chapter 13). Many financial self-help groups mirror social-economic changes (Bouman, chapter 22) and demonstrate their enormous adaptive capacities under macro-economic and political-administrative reform.

\section{Official Regulation}

There are countries in which the government is viewed as the sole grand designer of the landscape, in which every financial intermediary is licensed and controlled, his actions regulated, and the flow of funds directed towards prescribed sectors, in prescribed quantities to a prescribed number of clients; a landscape in which people deposit their savings with the officially recognized and approved banks. Unregulated curb markets and their representatives are seen as a disturbing factor that should be eliminated.

Conviction becomes reality. The maps drawn by official Indian and Thai statistics are a case in point. They depict a very substantial reduction of the share of informal credit in total cash debts of cultivating households from 70 percent in 1961 to 23 percent in 1981 in India (cf. Jones, chapter 18); in Thailand the share of informal loans has "officially" declined from about 90 percent to 30-50 percent between 1965 and 1991 (cf. Steinwand, chapter 17). These figures suggest that the so-called informal finance sector is rapidly disappearing from the financial landscape. But the landscapes drawn by Jones and Steinwand based on village studies, and supported by our own impressions in Maharashtra (Bouman 1989), show a much more robust and, moreover, positive presence of different informal intermediaries than is suggested by the official surveys and figures.

The official leaning towards discoloring of financial maps is reinforced by the fact that planners and consultants of development agencies persistently ignore the existence of financial curb markets. Even a publication on India's financial system by an authoritative source like the World Bank (Morriss 1985) does not devote one single paragraph to the subject. Yet, there are very few banks in rural areas in many developing countries, and none in remote locations. But there are many types of moneylenders, traders, pawnbrokers, ROSCAs and ASCRAs (cf. the different chapters in this book).

If we want to explore the rich variety of interrelations between different financial intermediaries, we need to question, however, the analytical value of the dualistic concepts of "formal" and "informal". These rather clumsy concepts not only violate the empirical diversity of financial intermediaries, they also assume the absence of direct or indirect links between traders, commercial banks, savings clubs, development banks, NGOs, and so forth (Benda-Beckmann 1992).

\section{Market Regulation}

There are financial sector specialists, commercial bankers and economists from international development agencies who view the "invisible hand" as the best designer of the landscape. They like to see the financial landscape as one great market, in which every financial intermediary is free to expand his services geographically and to set interest rates that will regulate the supply and demand for capital; a landscape without subsidies that will only ruin financial market places; a landscape in which people are preferably saving in financial assets that can easily be mobilized by commercial banks, subsequently investing their money abroad, in large industrial enterprises and/or in government bonds issued to finance the state deficit, that is, a landscape in which funds flow automatically to rewarding and secure opportunities. Again, informal financial agencies and arrangements are considered a disturbing factor because they reproduce "segmentation of financial markets", take care only of consumption needs and keep the national economy stagnant.

Unfortunately, the promotion of market mechanisms to structure relations between savers, lenders and borrowers is often based on a one-dimensional map of financial landscapes. Credit transactions and financial services are evaluated in terms of interest rates or transaction costs only, ignoring other stipulations of contracts between borrowers and lenders (contrast Adams, chapter 11) or barriers to credit access (contrast Zander, chapter 12). Credit relations that are embedded in wider social-economic relations are studied in isolation (contrast Hendriks, chapter 13). The rise and decline of different financial intermediaries and specific financial arrangements is not analyzed against the background of location-specific agro-ecological, economic, socio- 
legal and/or institutional conditions. These dimensions or multiple contexts of financial landscapes are simply left out or assumed to be a constant, in contrast to Abugre, Bouman, Crow, Harriss-White, Hospes and Southwold-Llewellyn, all in this volume.

The use of dualistic or black-white symbols to depict financial landscapes, such as "formal versus informal" and "consumption versus production loans", allows many bankers to marginalize the development role of "informal lenders". However, these distinctions are false and misleading. Loans for so-called consumption purposes can be of great importance for income-generating activities (cf. Abugre, chapter 10). Fridges are useful to make and sell ice; radios to listen to news of extension services; bicycles to transport chickens to the market; and medicines to cure the labor force. Not surprisingly, consumption loans do not necessarily represent a greater risk to lending agencies than so-called production loans (Heidhues, chapter 3). Besides, it is rather narrow to consider the use of loans for social security purposes, like housing, education, health and food, as counterproductive for "development". Likewise, to speak of "segmentation of financial markets" is not only to ignore possible links, either direct or indirect, between financial intermediaries, but also to underestimate the importance for savings clubs, traders, farmers or market women to limit their contacts with banks and cooperatives when the latter impose rigid rules or are simply not dependable.

\section{Multi-Disciplinary Approaches}

For a long time it has mainly been economists who have drawn the maps and colored the contours of the financial landscape. However great their skills, this has brought us maps of a very specific signature, now colored with the projections and symbols of liberalism, then of Marxism, then again of neo-classical and new institutional economics. Such maps can only be of limited use. "At the micro-economic level, the McKinnonShaw and neo-structural models are mute" warns Fry (1993: 24). The reconstruction of financial landscapes mirroring interlinked developments of state administrations, markets and communities, cannot and should not be the domain of one single discipline. Of necessity, its tools are inadequate to picture the immense variety of the landscape,

Multi-disciplinary approaches are called for to analyze and explain the diversity in forms of financial intermediation and the interrelations existing between them, in regulatory frameworks of financial intermediation, in scale and volume of operations and the variations that occur in time and space. To do that, we need to put finance in context and draw different maps of landscapes at macro and micro level.

Official statistics and estimates become suspect when measured in their true impact. Census data are aggregates, hiding more than they reveal about the underlying contrasts between different sectors of financial intermediation, nor do they do proper justice to the presence and impact of specific intermediaries at different points in history. Only painstaking micro-level research of finance in context, in combination with macro-level surveys, will portray the intricate, rich and vivid details of the landscape. This collection of readings is a mixture of both village and regional studies, using the colorful palette of interdisciplinary painting.

It is beyond this introductory chapter - and indeed beyond this book - to give a historical analysis of the infrastructure of financial landscapes through time and place, while simultaneously putting financial intermediaries and relations in multi-dimensionial contexts of development. But this book does contain a few chapters that summarily record historical particulars of certain financial intermediaries. Skully (chapter 21) analyzes how pawnbroking developed in Asia, and Bouman (chapter 22) discusses the gradual unfolding of different financial self-help groups in Nigeria. Crow (chapter 16) is the more colorful painter of historical landscapes, reviewing changes in rural finance in Bengal since the end of the nineteenth century. Schrader (chapter 20) is the more daring cartographer, going back to medieval times when putting moneylenders and merchant bankers in context in India and Indonesia. McLeod (chapter 6) picks up where Schrader left off, when he describes the evolution of financial policy in Indonesia since independence. Although none of the maps drawn by the respective authors can highlight all critical dimensions of (quasi)financial services in development processes, they all add important details that make our maps of these countries more complete.

\section{Cultivation of Financial Landscapes}

Whatever financial landscapes were before, they changed drastically in the twentieth century, more particularly in its second half. Early in this century colonial administrations, greatly impressed by the success of the cooperative movement in the Western hemisphere, began to introduce the cooperative model in the colonies. It marked the beginning of the plight of rural households, and of what Polly Hill (1982: 216) sees as "a colonial obsession with debt". With the exception of the informal agents, financial intermediaries were - and have always been - reluctant to extend their services to rural areas. Financing rural development was mostly limited to the estate sector; providing financial services to small farmers and other participants of micro-economies was an almost alien concept and was left to export firms working through intermediaries (cf. also Schrader in 
chapter 20). Such financing could now be left to cooperative savings and credit societies. Setting this cooperative movement on its feet became the self-proclaimed task of colonial authorities.

Progress was slow, and interrupted by two World Wars and the Great Depression. But between the 1950s and 1970s, when the former colonies became independent, rural development became a hot issue among major donor agencies and governments of Third World countries. The All India Rural Credit Survey of 1951 set the tone, when it revealed that over 90 percent of the rural population depended on the services of what since has been called the informal finance sector, while cooperative and government credit together accounted for a meagre seven percent. The resulting political indignation - somewhat hypocritical, considering that earlier Commissions of Enquiry had reported practically the same situation - sparked a long debate on finance and development that has strongly affected the contours of the present-day financial landscapes, not only in India, but worldwide.

\section{The Visible Versus Invisible Hand}

McLeod argues that two views on rural finance have dominated academic and political thinking in the postcolonial period. The first is a certain antipathy to informal finance, the second is "the notion that economic development can be encouraged by promoting financial development" (McLeod, chapter 6). This is certainly true, but the issues are rooted in much wider post-colonial debates.

Different battles had a profound influence on the views of financial landscapes. One was a political-ideological battle between adherents of capitalism and Marxist socialism, while some parties championed an intermediate "third way" and promoted cooperatives to structure social and economic life. The other was a battle between economists regarding the effects of official regulation and de-regulation of financial systems, or respectively the Keynesian and the Shaw-McKinnon models of growth. In the first few decades of the postcolonial period, adherents of official control of financial systems dominated policies and projects in the financial landscape, thereby shaping its contours. The cheap credit creed was one of their most dramatic brainchildren.

\section{The Cheap Credit Debate and Its Spin-Offs}

The population explosion in the newly independent states, the consequent diminution in the size of farms and gradual pauperization of the rural population, caused a rural exodus of hitherto unknown and frightening proportions that had to be stopped. Development of these countries became now equated with rural development, and this, in turn, with increasing agricultural output and rural incomes of small farmers in particular.

Although the Green Revolution promised bumper harvests, it required the application of costly new technology. According to adepts of neo-marxism, the fruits of the Green Revolution bypassed the small farmers due to their lack of capital, their victimization by moneylenders and traders, and the overwhelming influence of large farmers, landlords and other powerholders, who usurped all potential surpluses. Although often wary of this diagnosis, politicians and planners in developing countries as well as donor agencies agreed that the small farmer should be helped, and the logical remedy seemed to be to provide him with the necessary capital in the form of cheap loans. Since the informal finance sector was obviously the wrong circuit (see McLeod, chapter 6), it became the mission of formal institutions to do this. The financial landscape became dotted with rural banks, cooperatives, and specialized farm credit insitutions, while hundreds of billions of dollars were poured into countless projects that all claimed to have the well-being of the poorer strata of rural society at heart. It was the era of "small is beautiful", when low-priced small farmer credit became the major tool of rural development.

The cheap credit policy soon largely dominated the reconstruction of financial landscapes, not only in the physical sense through increased numbers of finance institutions, but also through changes in regulations regarding financial intermediation, manipulations by financial authorities, and the domination of research and political and scholarly debate. The world of students and planners of rural development became divided between antagonists and proponents of cheap farm credit, of "financial liberalization" versus what Shaw and McKinnon critically described as "financial repression". The now dominant views and issues of this debate are described by Seibel (chapter 2): many financial markets have now been deregulated and interest rates are no longer artificially kept low, but allowed to reflect so-called market conditions.

Various other authors, like Crow (chapter 16) and Hospes (chapter 14), do not so much take a position in the cheap credit debate but rather point at its weaknesses, demonstrating that the rate of interest is only one of the many determinants of savings and credit behavior. This brought an increasing number of students of rural sociology, legal anthropology, social geography and development economy to study the actual relations between savers, lenders and borrowers at micro level. Examples of studies of "multiple contracts" are Adams (chapter 11), Zander (chapter 12), Hendriks (chapter 13) and Southwold-Llewellyn (chapter 15) in our book. 
The opposition against the cheap credit creed led by Adams and his colleagues of the Ohio State University, however, had also more direct spin-offs. It greatly stimulated studies of financial institutions at local level, and brought a new interest in savings rather than loans and new insights on the sustainability of financial intermediation (cf. Von Pischke and Moll in chapters 4 and 5). It also brought a new understanding and recognition of the importance of the informal finance sector, that was ignored in the models of Shaw and McKinnon (Fry 1993: 18).

\section{The Rich World of Informal Finance}

Studies of financial intermediation in the curb market not only emphasized the ubiquity and universality of financial self-help groups (Bouman, chapter 7), but revealed also that the Green Revolution had ushered in new categories of lenders: rich farmers, having themselves profited from the Green Revolution, input suppliers, traders, millers and white- and blue-collar workers with a regular monthly income and access to banks - all acting as part-time moneylender and replacing the former professional moneylender of ill repute. Rural (and urban) financial landscapes in the 1970s and 1980s have thus undergone a major metamorphosis. Pawnshops have become second-hand goods stores selling unredeemed pawns, and financial self-help groups have diversified and grown - some of them handling millions of dollars - taking care of social security, insurance, local and regional investments, and improvement of infrastructure (Bouman, chapter 22). Linkages between these groups and banks have been established and new ones proposed (Seibel, chapter 2). The emphasis has shifted from the rural to the urban scene and from farms to non-farm micro enterprises (cf. Adams and Von Pischke, chapter 9). Now that commercial banks are no longer forced to finance small businesses and farmers, a task for which they are ill-equipped and which left a trail of degenerated financial eco-systems (Von Pischke, chapter 4), others are coming forward to fill the gap. The 1980s and 1990s are becoming the decades of the NonGovernmental Organizations (NGOs).

\section{NGOs: Filling or Falling in a Gap?}

A countless number of NGOs have taken up where others have left and continue a policy of cheap credit. In a report for the Conference on NGOs in October 1992 in The Hague, the number of NGOs in India alone is put at several millions! (Ghanshyam Shah 1992: 5). In the Philippines, the number of NGOs has grown to 17,000, while over 12,000 cooperatives were registered between 1987 and 1992 (Ghate, chapter 8). Although most NGOs are indigenous, many are supported by foreign donor parties from all spheres of life, representing a cross-section of society. Many of these donors are NGOs themselves.

During the past two decades, NGO policy has undergone a major shift in emphasis, from welfare and relief orientation to a policy centered on income generation. Provision of financial services for the poor - somewhat misleadingly called credit for micro enterprises - is one of the mainstays of this policy. Sometimes such provision is embedded in what is termed an "integrated development approach", encompassing "awareness building", training in all sorts of education that includes "skills", and health and housing programs. But increasingly, financial services are now provided without such extras and are labelled "minimalist programs", although technical training and management advice figure prominently in the brochures of quite a number of NGOs. Since most NGO staffs cannot boast of any such skills themselves, these brochures have to be taken with a grain of salt. Although most NGOs profess to aim at long-term viability and sustainability - magic words that are often heard but rarely addressed seriously by NGOs - the sad truth is that almost no organization or NGO could survive without heavy subsidies and grants from sympathetic, but ill-informed donors. The nagging doubt how long the efforts at filling a bottomless pit can last, has been vividly expressed by Abugre, arguing from personal experience that very few NGOs know anything about handling money, having always channeled but not managed funds.

The concept of the cost of money is still a strange one for many NGOs, including the big ones. Many times one comes across large credit funds managed by entirely unprofessional and untrained staff, the schemes themselves carelessly conceived, designed and implemented, generating an enormous waste and actually leading to either the indebtedness of the poor or their increased dependency on external support (Abugre, chapter 10).

Many NGOs have drawn fresh inspiration from the experience of the Grameen Bank (GB), the arche-type of successful financial intermediation for the poor. One could rightly argue that the success of the GB in Bangladesh has had a devastating effect elsewhere, in the sense that many NGOs have copied and are still trying to replicate the GB model. In the excitement about the GB success, an almost lone jewel in a series of mostly dismal failures, it is easily forgotten that this bank is, indeed, run by professionals, and yet is, after almost two decades of experimenting, still dependent on outside funds to survive. Moreover, replication 
contains its own dangers of introducing "dormant viruses" and adoption of a model "without a grasp of the substance that animates and sustains it" (Adams and Von Pischke, chapter 9). And, most importantly, the graveyards of public institutions and banks that toiled under the illusion that the poor could effectively be reached with cheap credit projects, have apparently never been visited by most NGOs. ${ }^{1}$

\section{Questions That Mark The Future}

Besides concern over the lack of expertise of NGOs in the field of finance, sincere doubts are warranted about the proficiency of banks to alleviate poverty by providing credit to the poor. McLeod is very clear in this respect: "Banks are simply not good at competing for this kind of business. What banks should be doing is simply what they are good at doing" (McLeod, chapter 6). These messages are not new, but are still not accepted by a large part of the international development community, still wrapped up in an ideology that feeds wishful rather than realistic thinking. The question remains what type of institution or agency is most apt to deal with handling financial services to low-income households in both rural and urban areas.

There are those who point out that low-income people in many countries have shown great capability and ingenuity at handling financial services themselves, with a proven potential to adapt to an ever-changing environment (Abugre, Bouman, Jones, Seibel and Steinwand in this volume). Yet another intriguing question remains: is this proof sufficiently convincing for us to abstain from any kind of financial or financial-organizational support? We believe that the answer to this question not only depends on the nature and extent of financial self-regulation, but also on the environment under which financial services are provided. For instance, for communities who recover from environmental, social or political crisis, and for dispersed populations in isolated areas,

the best option would include: not to inject substantial credit suddenly into rural financial markets, but instead to concentrate on stimulating the environment that stimulates informal savings and credit systems to flourish, pay more attention to physical infrastructure and communication and injecting capital slowly and progressively into the broader economy in general and the informal sectors in particular." (Abugre, chapter 10)

A differentiated view of contexts can be of great help in better assessing what kind of direct or indirect support is appropriate in what region or situation, but also in deciding when credit supply or linkage-building is not due: "Under conditions of turbulence, it may make more sense not to substantially interfere with informal financial systems that work" (Abugre, chapter 10). In case of ecological crisis, political turmoil, economic decline but also financial and monetary instability, the indigenous systems might be very important devices of low-income people to restrict mobility of scarce financial funds. It would then not be very wise to pursue a development policy directed at integration of financial markets in which the allocation of financial resources is determined by the marginal productivity of capital. This might shift away scarce financial resources of marginalized groups who need and prefer to invest in subsistence security, education and housing (Eldijk 1992).

A contextual approach to the promotion of financial self-help organizations implies a greater emphasis on the creation of an environment that enables them to flourish and shape their own development. With regard to financial and monetary instability, for instance, the organization of finance at the fringes might be best served when at the core of financial systems there is established a competitive banking system placed under the effective control of a properly managed central bank (Eldijk 1992). When banks become dependable institutions that gain people's trust, linkages between financial self-help groups and nearby banks will evolve automatically. When the local currency is quite stable, participation in ROSCAs and ASCRAs to finance funeral expenses, house construction material or working capital, can be more attractive.

After having witnessed the destruction of financial landscapes through an overkill of credit by international donors, government organizations and NGOs - getting in each other's way, even competing with each other with too liberal doses of cheap funds - it is time now to study finance in context and to develop policies and projects that mirror region- and location-specific circumstances and grant much more respect to financial selfregulation.

1. Concern over the wild growth and unprofessionalism in the financial landscape created by the NGOs, was involuntarily fueled by experience at the seminar. Of the NGOs invited, a few presented only a brochure that spelled out there activities, but no paper that tried to sum up and appraise their effords at financial intermediation in context. Others were represented by consultants who did present such a paper, of which, unfortunatedly, only two could meet the standard set by the organisation of the Seminar 


\section{References}

Benda-Beckmann, F. von. 1992. Welcome Adress at the Seminar "Financial Landscapes Reconstructed", Wageningen Agricultural University, The Netherlands.

Bouman, F.J.A. 1989. Small, Short and Unsecured: Informal Rural Finance in India. Delhi: Oxford University Press.

Eldijk, A. van. 1992. "At the Crossroads of Financial Landscapes". Paper presented at the closing of the Seminar "Financial Landscapes Reconstructed", Wageningen Agricultural University, The Netherlands.

Fry, Maxwell J. 1993. Financial Repression and Economic Growth. International Finance Group, University of Birmingham.

Hill, Polly. 1982. Dry Grain Farming Families: Hausaland (Nigeria) and Karnataka (India) Compared.

Cambridge University Press.

Morriss, F. 1985. "India's Financial System: An Overview of Its Principal Structural Features". Washington: World Bank. Staff Working Paper no. 739.

Ghansyam Shah. 1992. "Non-Governmental Organizations in India”. Report for the Conference on NGOs. The Hague. 